DOI https://doi.org/10.18551/rjoas.2017-09.08

\title{
ANALYSIS OF THE EFFECTS OF ECONOMIC GROWTH, INVESTMENT, REGIONAL TAXES, AND CAPITAL EXPENDITURE TOWARD THE INCOME DISPARITY IN INDONESIA (2007-2013)
}

\author{
Hardanto $H_{.}^{*}$, Ismail M., Khusaini M. \\ Faculty of Economics and Business, University of Brawijaya, Indonesia \\ *E-mail: heruhard@yahoo.co.id
}

\begin{abstract}
This research is aimed to examine the effects of economic growth, Foreign Direct Investment, regional taxes, and provincial regional capital expenditure toward the income disparity in Indonesia from 2007-2013. This research utilized panel data composed from 33 provinces in Indonesia from 2007-2013 (231 observations). The method used in this research was regression analysis of panel data using Fixed Effect Model. Research results showed that economic growth and regional taxes had a positive influence toward the income disparity. Capital expenditure affected the income disparity negatively. Meanwhile, foreign direct investment had no effect on the income disparity.
\end{abstract}

\section{KEY WORDS}

Income disparity, economic growth, FDI, regional taxes, capital expenditure.

Economic growth is one of the indicators of development success, in addition to the other indicator of income distribution. From the standpoint of economic growth, Indonesia continues to experience an increase in per capita output per year, which is shown by the increase in gross national per capita income. According to World Bank data, the gross national per capita income of Indonesia increased from US\$ 560 in 2000 to US\$ 3.630 in 2014. Even though there was an increase of per capita output, the income disparity in Indonesia as measured by the Gini Coefficient (Gini Index) instead tends to experience an increase. Based on data from the Central Statistics Agency (Badan Pusat Statistik, BPS), the Gini Coefficient of Indonesia has risen from 0.36 in 2006 to 0.41 in 2013.

The Gini Coefficient of Indonesia since 2011 has exceeded 0,40, which is the international warning level for a dangerous disparity level. Globally, since 2011 Indonesia could be categorized as a country with a low income and a high income disparity, shifting from a low-income country with a low income disparity in the previous decade (Yusuf, 2014).

Much attention has been given on how the income disparity appears in the time of economic growth. According to Galbraith and Kum (2012), the relationship between income disparity and economic growth began to receive attention when Simon Kuznets explained his hypothesis. According to Kuznets, in the early stage of development, initially the income distribution becomes more uneven, but income distribution will become more even after reaching a certain level of development. Several studies and their findings confirm the view of Kuznets, among them including Park and Shin (2015) and Cevik and Caro (2015). However, several studies also did not support the view, an example being the study carried out by Khasru and Jalil (2004). Several studies showed that economic growth did not affect the income disparity (Schultz (1998), Deininger and Squire (1998), Ravalion and Chen (1996).

Because of these differences in study results regarding the effect of economic growth on the income disparity, there needs to be research on whether economic growth in various provinces in Indonesia is able to reduce the income disparity or instead make the income disparity deeper and even worse.

Based on the results of other studies, there is another factor that may also encourage economic development and affect income disparity, and that is investment. Investment plays important roles in encouraging development in a country, and thus this is often called as an "engine of growth" by economists. According to Mundell (1957) and Bhandari (2007), an 
increase in the flow of investment will reduce the disparity in the distribution of income. Conversely, according to Freeman (2010), Mah (2002), and Lipsey and Sjoholm (2001), the entry of investment, in particular foreign direct investment (FDI), causes an increase of the income disparity. Yet the results of studies by Mah (2003) and Sylwester (2005) show that FDI did not have an effect on income distribution.

Based on data from the Central Statistics Agency, the realization of foreign direct investment (FDI) in Indonesia in 2007 was US\$ 10,341.4 and in 2013 this increased to US\$ 28,617.5. Thus in the time frame within 2007-2013 there was an increase of investment by US\$ 18,276.1. Seeing the magnitude of foreign investment, research then needs to be conducted on whether foreign investment has been able to encourage development and overcome the income disparity.

Yet another factor that may affect the distribution of income is government policies. According to Todaro (2011), the government may perform intervention through government policies to change the distribution of income. This form of government intervention is through the application of government budget expenditure and taxation policies. Since entering the era of regional autonomy in 1999, the Indonesian government has provided greater authority to regional governments in regulating, taking advantage of, and uncovering potential sources in each region. One of the forms of this authority is that regional governments can determine regional tax and budget expenditure policies. One of the goals of this decentralization of authority is to equalize regional development. Regional autonomy has been implemented for over a decade, and therefore it is necessary to see whether government policies through the application of regional taxes and government expenditure has been able to increase the equalization of income distribution or to overcome the income disparity.

Considering that research that discusses discrepancies using provinces as the unit of analysis has been limited, this research was conducted. The objective of this research is to analyze the effects of economic growth, foreign direct investment, regional taxes, and capital expenditure toward the income disparity in Indonesia.

\section{LITERATURE REVIEW}

The relationship between economic growth and disparity began to surface when the economist Simon Kuznets put forth his upside-down $U$ hypothesis (Galbraith and Kum, 2012). According to Kuznets, income distribution at an early stage tends to worsen, but in the following stages, the distribution will improve. Because the shape of the curve of changing tendencies of income distribution (Gini Coefficient) and the per capita Gross Domestic Product growth appears to resemble appears to resemble the shape of an upside-down letter " $U$ ", this hypothesis is known as the upside-down $U$ hypothesis of Kuznets. Income distribution, according to Kuznets, will increase along with economic growth (Todaro, 2000).

Neoclassical economists explain that while still at an early stage, economic growth will tend to reduce the disparity of income and poverty. Meanwhile, Karl Marx (in Irawan 2012) had the opinion that at an early stage of development, economic growth will cause demand for labor to increase. The increasing rate of wages of laborers will affect the increase of capital risk for laborers, which will cause a decrease in the demand for labor. This situation will create a problem of unemployment and income disparity. Thus, it is only at the early stage that economic growth tends to be able to reduce poverty and the income disparity; in the next stage, the opposite will occur.

Results of research by Park and Shin (2015) showed that financial and per capita income growth in several developed countries affected the income disparity at certain levels of per capita income accordingly to the upside-down $U$ curve hypothesis of Kuznets. In contrast, the opposite was found by Khasru and Jalil (2004) from their research with time

series data and panel data from 24 countries, where results indicated that the effect of economic growth did not conform to the upside-down $U$ curve pattern by Kuznets.

Lin (2003) conducted research on the effect of economic growth on the income disparity and reduction of poverty in the People's Republic of China within the years of 19852001. The result was that economic growth negatively affected poverty but positively 
influenced the income disparity. Meanwhile, Kang (2015) found that economic growth correlated negatively toward income disparity. Similar results were obtained by Psacharopoulos et al. (1995) with research of Latin American countries that showed that economic growth negatively affected the income disparity.

Deininger and Squire (1998) found that economic growth did not affect the income disparity significantly. Similar findings were obtained by Ravalion and Chen (1996) where the aggregate income increase in several developing countries did not significantly affect the reduction of the income disparity.

Foreign Direct Investment (FDI) becomes one of the important sources of funding for a developing country. According to Mundell (1957), an increase in the flow of Foreign Direct Investment (FDI) in a developing country will reduce the disparity in income distribution. The increase of FDI flows from developed countries to developing countries through the increase of available capital will result in the marginal increase of physical product from laborers. This will in turn increase nominal wages as well as real wages, reducing the income disparity.

Feenstra and Hanson (1997) have the view that capital flows from developed countries to developing countries will cause an increase in the demand for skilled labor (seen from the view of developing countries). This will increase the relative wages for those laborers. As such, wages will improve for skilled laborers and conversely for unskilled laborers, wages do not improve. Thus the primary consequence of FDI flows to developing is the increase of the disparity on income distribution.

Research results by Bhandari (2007) indicated that investment negatively affects the income disparity. Dabla-Norris et al. (2015) found that investment will have a positive influence in increasing the disparity in developed countries. Meanwhile in developing countries, foreign direct investment does not have an influence on the disparity.

Figini and Gorg (2006) found that FDI had a different influence on the income disparity. In developing countries, investment will first have a positive influence on the income disparity, and then in later times will influence the income disparity negatively. Meanwhile in developed countries, investment will have a negative influence on the income disparity. Also, Mihaylova (2015) found that the influence of FDI on the disparity can vary depending on the levels of development, education, and economy in the countries targeted for investment.

Mah (2002) and Lipsey and Sjoholm (2001) found that FDI caused the increase of the income disparity. Yet Mahler et al. (1999), Sylwester (2005), and Mah (2003) found that the expansion of FDI does not significantly affect the disparity of income distribution in developing countries.

In relation to the influence of taxes on the income disparity, llaboya (2013) found that tax revenue negatively affected the income disparity. As well, Martinez-Vazquez et al. (2014) found that the share of individual progressive income tax on the GDP had a positive influence on the distribution of income or in other words reduce the income disparity. On the other hand, consumptive taxes, excise taxes, and import duties instead increased the income disparity. A greater share of social prosperity expenditure on the GDP was able to reduce the income disparity.

Musgrave and Rostow in Mangkoesoebroto (1998) created a development model that related development from government expenditures with the stages of state economic developmental growth. In the early stage of economic development, there needs to be major state expenditures for investment, in particular to provide infrastructure. In the middle stages of economic development, government investment is still needed for economic growth, but at this stage investment from the private sector has begun to develop. In the advanced stages of economic development, government expenditures are still necessary, in particular to increase the welfare of the people.

One of the government expenditures to increase the welfare of the people is capital expenditure. One of the uses of capital expenditure is for the construction of public infrastructure that the people need. According to Estache (2003), infrastructure can aid impoverished people and those living in backward regions to become connected with important economic activities, which allow the people to obtain additional productive opportunities. 
Holzner (2011) found that government expenditures correlated negatively toward the income disparity. Conversely, Sabir et al. (2015) found that government expenditures had a positive influence on the income disparity.

\section{METHODS OF RESEARCH}

In this research, the utilized type of data was secondary data. The utilized data was in the form of panel data, which combines the two types of time series and cross section data. This research combines time series data of a time frame of seven years from 2007-2013 as well as cross section observations of 33 provinces in Indonesia (231 observations). Analysis using panel data has the advantage of allowing the researcher to examine deeper the economic effects that cannot be obtained if the researcher only uses either time series or cross section data. Several of the methods used in performing estimations with panel data regression are the Common Effect (CE) Model, Fixed Effect (FE) Model, and Random Effect (RE) Model. The Chow and Hausman tests are used to determine the most appropriate regression estimation. Analysis of panel data in this research uses the Eviews 7 program.

Mathematically, the form of the regression equations for the panel data in this research can be formulated as:

$$
\text { GINlit }=\beta 0+\beta 1 \text { GROWit }+\beta 2 \text { FDlit }+\beta 3 \text { TAXit }+\beta 4 \text { SPCAPit }+\varepsilon i t
$$

Where: GINI is the income disparity (Gini Ratio); GROW is economic growth (as a percent); FDI is foreign direct investment; TAX is the regional tax of the provincial government; SPCAP is the capital expenditure of the provincial government; and $\varepsilon$ is error.

To avoid incorrect understandings and to narrow down the coverage of the problems in this research, the following are the operational definitions of each research variable:

Income disparity in this research is the income disparity that is measured using the Gini Index in each province in Indonesia. The Gini Index was taken from the Central Statistics Agency (Badan Pusat Statistik, BPS).

Economic growth is the growth in per capita gross regional domestic product (GRDP) from the constant price base in the year 2000 in each province (as a percent). The per capita GRDP growth data from the constant price base in 2000 was taken from the Central Statistics Agency.

Foreign direct investment is the ratio of foreign direct investment toward the GRDP in each province in the time frame of 2007-2013 (as a percent). Data of foreign direct investment (FDI) realization was taken from the Investment Coordinating Board (Badan Koordinasi Penanaman Modal, BKPM) and GRDP data was taken from the Central Statistics Agency. The value of FDI realization ratio is calculated by dividing the FDI realization value by the GRDP. Because the FDI value is in US dollars and the GRDP is in rupiahs, to calculate the ratio of FDI to GRDP, unit conversion is performed on the GRDP from rupiahs to US dollars by dividing the GRDP of each year by the yearly average exchange value of the rupiah to the US dollar. Data of the yearly average exchange value was taken from Bank Indonesia.

Regional tax of the provincial government is the ratio of realization of provincial tax revenue toward the GRDP of each province in the time frame of 2007-2013 (as a percent). Data of the realization of provincial tax revenue and the GRDP were taken from the Central Statistics Agency. The ratio of realization of provincial tax revenue is obtained by dividing the realization of tax revenue by the GRDP value of the same year.

Capital expenditure of provincial governments is the ratio of realization of capital expenditure of provincial governments toward the GRDP of each province in the time frame of 2007-2013 (as a percent). Data of the realization of capital expenditure and the GRDP were taken from the Central Statistics Agency. The ratio of realization of capital expenditure of provincial governments is obtained by dividing the realization of capital expenditure by the GRDP value of the same year. 


\section{RESULTS AND DISCUSSION}

In the analysis of panel data with the bound variable of income disparity (GINI) and free variables of economic growth (GROW), investment (FDI), regional taxes (TAX), and capital expenditure (SPCAP), the Chow Test and Hausman Test were performed to obtain the most appropriate regression model.

Based on the results of the Chow Test with Eviews, a Chi-square probability value of 0.0000 was obtained, less than the significance value $\alpha$ of $0.05(\alpha=5 \%)$. This shows that the fixed effect model was better compared to the common effect model (pooled least square). The results of the Hausman Test showed a Chi-square probability value (Prob.) of 0.0005 , less than the value of $\alpha$ of $0.05(\alpha=5 \%)$. This shows that the fixed effect model was better compared to the random effect model. Thus, the best model used to estimate the regression of panel data in this research was the fixed effect (FE) model.

Using the fixed effect (FE) model for analysis of panel data, these estimation results were obtained:

Table 1 - Regression Results

\begin{tabular}{|c|c|c|c|}
\hline Variable & Coefficient & $t$-Statistic & Probability \\
\hline Constant (C) & 0.273525 & 22.51559 & $0.0000^{*}$ \\
\hline Economic Growth ( GROW) & 0.001480 & 2.026599 & $0.0441^{*}$ \\
\hline Foreign Direct Investment (FDI) & 0.000386 & 0.863960 & $0.3887^{*}$ \\
\hline Regional Tax (TAX) & 0.081643 & 7.482308 & $0.0000^{\star}$ \\
\hline Capital Expenditure(SPCAP) & -0.010536 & -2.771299 & $0.0061^{*}$ \\
\hline
\end{tabular}

$R$-squared: 0.652748

Adjusted R-squared: 0.588310

F-statistic: 10.12979

Prob. (F-statistic): 0.000000

Note: $\left(^{*}\right)$ significant for $\alpha=5 \%$

Based on the results of regression above, it can be seen that economic growth (GROW) had a positive influence toward changes in the variable of income disparity (GINI). This means that as economic growth (growth in per capita GRDP) escalates, this will also increase income disparity.

As such, economic growth will instead worsen the income disparity. Referring to the view of Kuznets, the stages of development in provinces in Indonesia could still be at the early stage of development, where economic growth worsens the income disparity instead. This may be because of the still-unequal opportunities and access toward economic resources for all people or economic actors in various provinces.

The results of this research supports the research of Lin (2003) who found that economic growth positively affected the income disparity and negatively affected the poverty rate. Meanwhile, the group of Neo-Marxist economists have the view that economic growth will cause the disparity between rich people and poor people to widen further. In contrast, the results of this research do not reflect the views of Neoclassical economists, that economic growth will reduce the income disparity (negative effect to the disparity) even in the early stages of economic development.

Meanwhile, based on the results of the above regression, the variable of foreign direct investment (FDI) has a $\mathrm{t}$ statistical probability value of 0.3887 ; hence foreign direct investment did not significantly affect the income disparity. These results do not reflect the theory of Mundell (1957), who stated that an increase in Foreign Direct Investment (FDI) flow in developing countries will reduce the disparity in the distribution of income.

The variable of regional tax (TAX) based on the results of the regression had a $t$ statistical probability value less than the value of $\alpha=0.05$. With this, regional taxes will have a positive influence on the income disparity. This means that every increase in regional taxes will increase the income disparity. 
According to Law No. 28 of 2009, regional provincial taxes are composed of the Motor Vehicle Tax, Motor Vehicle Transfer Fee, Motor Vehicle Fuel Tax, Surface Water Tax, and Cigarette Tax. These five regional taxes above are included as consumption taxes. The Surface Water Tax, Cigarette Tax, and Motor Vehicle Fuel Tax are indirect taxes on consumption. From the above fact, it can be seen that regional taxes and in particular provincial taxes are more dominated by indirect taxes. This result is also supported by the research of Chu (2000), where it was stated that the structure of taxes in developing countries are dominated by indirect taxes with a limited portion of capital taxes and income taxes.

There is the tendency that these indirect taxes on consumption in regional taxation are more regressive than progressive in nature. According to de Wulf in Chu (2000), research in developing countries show that it is difficult to not conclude that the taxation system in developing countries are surely regressive. The basis of this rationale is the relative dominance of consumptive taxes, which are assumed to be mostly regressive in nature. These research results are supported by the research of Martinez-Vazquez et al. (2014), where the application of taxes on consumption will increase the income disparity.

Meanwhile, the variable of capital expenditure (SPCAP) based on the results of the regression had a t statistical probability value of less than the value of $\alpha=0.05$. Thus capital expenditure will negatively and significantly affect the income disparity. This means that each time capital expenditure increases, this will reduce the income disparity.

According to Todaro (2011), increasing the distribution of income (reduce the income disparity) at the lowest level (impoverished people) can be done using the budget expenditure of the government. One way of doing this is by increasing the income of impoverished people indirectly through the construction of infrastructure that is funded by government spending. For the case of Indonesia, the government budget expenditure that is most frequently utilized for the construction of public infrastructure is capital expenditure.

The construction of infrastructure can provide a positive effect on the income of impoverished people. Conceptually, infrastructure can aid impoverished people and backward regions to become connected with important economic activities that enable them to obtain additional productive opportunities (Estache, 2003). Construction of infrastructure in backward regions also reduces production and transaction costs (Gannon and Liu, 1997). Calderon and Serven (2004) who researched the influence of infrastructure on the level of economic growth and income disparity in developed and developing countries found that quantity and quality of infrastructure negatively affects the disparity of income.

\section{CONCLUSION}

This research using panel data from 33 provinces in Indonesia within 2007-2013 examined the effects of economic growth, investment, regional taxes, and capital expenditure toward the income disparity. From the results of this research four conclusions can be obtained. First, economic growth has a positive influence toward the income disparity in Indonesia. Second, investment (FDI) does not significantly affect the disparity of income. Third, regional taxes have a positive influence on the income disparity. This occurs because the structure of regional taxes which are primarily in the form of indirect taxes on consumption, which tends to worsen the income disparity. Fourth, capital expenditure has a negative influence on the disparity of income. The utilization of capital expenditure in particular for the provision of public infrastructure allows the people to obtain additional productive opportunities to increase their income.

\section{REFERENCES}

1. 2008. Statistik Indonesia 2008. Jakarta: BPS

2. 2009. Statistik Indonesia 2009. Jakarta: BPS

3. 2010. Statistik Indonesia 2010. Jakarta: BPS 
4. 2011. Statistik Indonesia 2011. Jakarta: BPS

5. 2012. Statistik Indonesia 2012. Jakarta: BPS

6. 2013. Statistik Indonesia 2013. Jakarta: BPS

7. 2014. Statistik Indonesia 2014. Jakarta: BPS

8. 2011. Pembangunan Ekonomi jilid 1 edisi kesebelas. Jakarta: Erlangga

9. 2011. Statistik Keuangan Pemerintah Provinsi 2007-2010. Jakarta: BPS

10. 2012. Statistik Keuangan Pemerintah Provinsi 2008-2011. Jakarta: BPS

11. 2014. Statistik Keuangan Pemerintah Provinsi 2010-2013. Jakarta: BPS

12. 2016. Statistik Keuangan Pemerintah Provinsi 2012-2015. Jakarta: BPS

13. Badan Pusat Statistik. 2007. Statistik Indonesia 2007. Jakarta: BPS

14. Bhandari, Bornali. 2007. Effect of Inward Foreign Direct Investment on Income Inequality in Transition Countries. Journal of Economics Integration 22(4), December 2007;888-928

15. Calderon, C., and Serven, L. 2004. The Effect of Infrastructure Development on Growth and Income Distribution, vol 3400, World Bank Policy Research Working Paper. Washington, DC: The World Bank

16. Cevik, S. and Caro. C. 2015. Growing (Un)equal: Fiscal Policy and Income Inequality in China and BRIC+. IMF Working Paper No. 68

17. Chu, Ke-young., H. Davoodi, and S. Gupta. 2000. Income Distribution and Tax, and Government Social Spending Policies in Developing Countries. IMF Working Papers WP/00/62, Washington DC

18. Deininger, K. and Squire, L. 1998. New ways of Looking at Old Issues: Inequality and Growth. Journal of Development Economics, 57(2), 259-287

19. Estache, A. 2003. "On Latin America's Infrastructure Privatization and its Distributional Effects." Washington, DC: The World Bank, Mimeo

20. Feenstra, R. and Gordon Hanson. 1997. Foreign Direct Investment and Relative Wages: Evidence from Mexico's Maquiladoras. Journal of International Economics 42, 371-393

21. Figini, P., dan Holger Gorg. 2006. Does Foreign Direct Investment Affect Wage Inequality? An Empirical Investigation. IZA Discussion Paper No.2336, September 2006

22. Freeman, R. 2010. "Does Inequality Increase Economic Output?" In Controversies about Inequality. Stanford, CA: Stanford University Press

23. Galbraith, J. K., and Hyunsub Kum. 2012. Inequality and Economic Growth: Data Comparations and Econometric Tests. UTIP Working Paper Number 21

24. Ganon, C.and Liu, Z. 1997. "Poverty and Transport." Washington, DC: The World Bank, Mimeo

25. Holzner, M. 2011. Inequality, Growth and Public Spending in Central, East and Southeast Europe. Working Paper, 221.

26. Ilaboya, O.J., and N. Ohonba. (2013). Direct Versus Indirect Taxation and Income Inequality. European Journal of Accounting Auditing and Finance Research, Vol.1 No.1, March 2013, pp.1-15

27. Irawan, M. Suparmoko. 2002. Ekonomika Pembangunan Edisi ke 6. Yogyakarta: BFE

28. Kang, J.W. 2015. Interrelation Between Growth and Inequality. ADB Economics Working Paper Series No. 447

29. Khasru, S.M. and Jalil, M.M. 2004. Revisiting Kuznets Hypothesis; An Analysis with Time Series and Panel Data. The Bangladesh Development Studies vol. xxx, SeptemberDecember 2004, No. 3 \& 4

30. Kuncoro, Mudrajad 2004. Ekonomi Pembangunan: Teori Masalah dan Kebijakan, UPPAMP YKPN, Yogyakarta.

31. Kuznets, S. 1955. Economics Growth and Income Inequality. An American Economic Review, Vol. No. 45, 1-28

32. Lin, B.Q. 2003. Economic Growth, Income Inequality, and Poverty Reduction in People's Republic of China. Asian Development Review 20: 105-124

33. Lipsey, R. and Sjoholm, F. 2001. Foreign Direct Investment and Wages in Indonesian Manufacturing. National Bureau of Economics Reseach (NBER). Working Paper. No.1925 
34. Mah, J.S. 2002. The Impact of Globalization on Incom Distribution: The Korean Experience. Applied Economics Letters. 9 (15). Pp. 1007-1009

35. Mah, J.S. 2003. A Note on Globalisation and Income Distribution - The Case of Korea, 1975-1995. Journal of Asian Economics 14, 157-164

36. Mahler, A., Jesuit, K., Roscoe, D. 1999. Expolring the Impact of Trade and Investment on Income Inequality. Comparative Political Studies 32, 3, 363-395

37. Mangkoesoebroto, Gurit. 1998. Kebijakan Ekonomi Publik di Indonesia: Substansi dan Urgensi. Jakarta: Gramedia Pustaka Umum

38. Martinez-Vazquez, J., Vulovic, V. and Dodson, B.M. (2014). The Impact of Tax and Expenditure Policies on Income Distribution: Evidence from a Large Panel Countries. Hacienda Publica Espanola / Review of Public Economies, 200-(4/2012): 95-130

39. Mihaylova, Svilena. 2015. Foreign Direct Investment and Income Inequality in Central and Eastern Europe. Theoretical and Applied Economics Vol. XXII (2015), Summer, pp.23-42

40. Mundell, R. 1957. International Trade and Factor Mobility. The American Economic Review 47, 3, 321-335

41. Park, D. and Shin, K. 2015. Economics Growth, Financial Development, and Income Inequality. ADB Economics Working Paper Series No. 441

42. Psacharopoulos, G. Morley, S., Fiszbein, A. Lee, H. and Wood, W. 1995. Poverty and income inequality in Latin America during the 1980s, Review of Income and Wealth, series 41, No. 3, pp. 245-64, Sep. 1995

43. Ravallion, M. and Chen, S. 1996. What can new survey data tells us about recent changes in distribution and poverty? The World Bank Economic Review, 11 (1), 345-361

44. Sabir, Ahmad Erani Yustika, Susilo, Ghozali Maskie. 2015. Local Government Expenditure, Economic Growth and Income Inequality in South Sulawesi Province. Economic Department Hasanuddin University

45. Schultz, T.P. 1998. Inequality in the Distribution of Personal Income in the World: How It Is Changing and Why. Journal of Population Economics, August 1998, v. 11, iss. 3, pp. 307-44

46. Sukirno, S. 1996. Pengantar Teori Makroekonomi. Jakarta: Raja Grafindo Persada

47. Sylwester, K. 2005. Foreign Direct Investment, Growth and Income Inequality in Less Developed Countries. International Review of Applied Economics 19, 3, 289-300

48. Todaro, M.P. dan Smith, Stephen. 2000. Pembangunan Ekonomi di Dunia Ketiga. Jakarta: Erlangga

49. Yusuf, Arief Anshory. 2014. Trend of Inequality in Indonesia. Keynote address delivered in a workshop on, "Mapping the Impact of inequality in Indonesia. SMERU research Institute, Jakarta. 